\title{
The Organization of Social Sustainability Work in Swedish Eco-Municipalities
}

\author{
Lisa Wälitalo *(1) and Merlina Missimer [D
}

Citation: Wälitalo, L.; Missimer, M.

The Organization of Social

Sustainability Work in Swedish

Eco-Municipalities. Sustainability 2022, 14, 2770. https://doi.org/

$10.3390 /$ su14052770

Academic Editor: Roope Husgafvel

Received: 1 December 2021

Accepted: 22 February 2022

Published: 26 February 2022

Publisher's Note: MDPI stays neutral with regard to jurisdictional claims in published maps and institutional affiliations.

Copyright: () 2022 by the authors Licensee MDPI, Basel, Switzerland. This article is an open access article distributed under the terms and conditions of the Creative Commons Attribution (CC BY) license (https:/ / creativecommons.org/licenses/by/ $4.0 /)$.

\author{
Department of Strategic Sustainable Development, Blekinge Institute of Technology, \\ SE-37179 Karlskrona, Sweden; mis@bth.se \\ * Correspondence: lwo@bth.se
}

\begin{abstract}
Even though large parts of a municipal administration's work are aligned with social sustainability, this dimension has been somewhat more challenging and there seems to be a vast diversity in how it is approached. Academic literature on the systematic organization of this work is sparse. The aim of this study was to understand how Swedish municipalities organize their work with social sustainability and to find best practices. A survey among 21 municipalities and follow-up interviews with three of them were conducted. The study revealed that the organization of social sustainability work varies considerably among municipalities and that no simple patterns relating to size or existing organizational structures can be detected. Each municipality seems to be finding its own way and is more or less successful in strategically working with this area. Best practice focused on creating additional structures for collaboration across departments, with external actors, and across sectors to at least partly overcome the silo approach engrained in a municipal structure. It was also connected to the active involvement of leaders, clear mandates, and that a common vision for social sustainability was communicated. These lessons can be transferred to other municipalities and help them move towards social sustainability in a strategic way.
\end{abstract}

Keywords: local administration; social sustainability; strategic sustainable development; municipal planning

\section{Introduction}

Municipal administrations are considered key players in addressing our current sustainability challenge [1]. Scholars have studied and analyzed work and processes for overall sustainability in municipalities, e.g., [2-5]; how it is organized seems relatively easy to identify in a municipal administration as well as in the surrounding community. Challenges and barriers for the work have also been identified [6-8]. Thus, it is possible to follow up the work, and strategically and systematically improve, for example, through identifying people and operations involved in concrete and easily demarcated areas such as energy or transportation and to create functions and structures to coordinate and address them in collaboration, e.g., [9-11].

To solve ecological sustainability challenges such as climate change or biodiversity loss, however, it is important to simultaneously address social sustainability issues [12]. The complexity of the combined sustainability challenge [13] and the fact that specifically social sustainability is defined in various ways $[14,15]$ lead to multiple interpretations and ideas of what systematic and strategic work could look like for municipal administration. Even though it is a large part of a municipal administration's responsibility [16-18], there seems to be a vast diversity in how municipalities approach social sustainability, and it does not seem easy to account for how work is generally understood and structured. Thus, the contours of social sustainability work in this context are diffuse.

Broman and Robért [19] argued that to address this complex challenge and to enable strategic collaboration between organizations and many different actors, and for them to aim for a common vision of success, they need to share a common understanding and 
vocabulary for the challenge. Further, Woodcraft [20] concluded that closer attention is needed to understand practical and operational aspects of social sustainability to be "used as justification for making decisions about interventions and investments in the material and social fabric of cities" [20] (p. 40). In other words, to consciously adapt and apply strategic support to improve work for social sustainability in specific, and to find potential synergies with ecological and economic sustainability measures, an understanding of how work is understood and organized is vital.

The concept of social sustainability in municipalities has been mapped to some extent [14,21-23], and scholars give perspectives such as exploring 'just city principles' [24], understanding [25] and measuring social sustainability of neighborhoods [26], and reviewing current trends on urban social sustainability [27].

In a Swedish context, Gustavsson et al. [28] explored social sustainability in eight urban construction projects, which led to a strategy for the analysis of social sustainability in ongoing and future urban construction projects. The authors identified three nuances of social sustainability (social inclusion, participation, and place identity) and gave examples of goals, measures, and indicators in relation to them. However, the municipal system perspective of coordination and collaboration between many actors that covers the broad municipal context is not mapped. Holmström and Karlsson [29] analyzed the application of social sustainability in Swedish municipal planning, with a focus on spatial planning. Their study provided some good insights of social sustainability work in Swedish municipalities, such as how clearer collaboration within the organization supports social sustainability work. However, these studies did not take a full system's perspective on social sustainability, that is, how the municipal administration as an important facilitator to coordinate work strategically, both internally and externally, conducts its work within the system of the geographic municipality.

Krause et al. [4] provided insights on the administrative organization for sustainability within a local government in a US context. From analyzing factors that influence the placement of organizational functions (such as governmental capacity, policy characteristics, and institutional structure), a considerable variation of the organizational locus (structure and location) across cities was noted. The authors emphasized support from elected officials as an important force and favored specialized and centralized units with sustainability responsibility. However, they did not look specifically at the social sustainability dimension.

In the absence of academic studies related to the structure and organization of systemsbased social sustainability work in municipal administration, we turned to public information and gray literature. Most prominent in the current Swedish context is the 'Social Sustainability Forum' run by The Swedish Association of Local Authorities and Regions (SALAR) [30] and the Swedish Public Health Agency [18]. The forum was formed to exchange knowledge and experience to develop welfare in a socially sustainable way and is open to elected representatives, civil servants, and researchers in municipalities, regions, the state, businesses, and civil society organizations. However, no reports are to be found of a current state in how municipalities structure their social sustainability work in this context. Nevertheless, an interesting and, for this study, relevant report on municipalities' work on social sustainability [31] was found via a Swedish National Municipal Research Program that ran between 2011 and 2017 [32]. The program was coordinated by four Swedish municipal research institutes (in Gothenburg, Linköping, Lund, and Stockholm) and focused on different themes (such as 'Collaboration as strategy' and 'What is municipal growth?') developed in collaboration between researchers and participating municipalities (47 municipalities in phase one and 26 in phase two). The program's purpose was to systematically follow developments in the municipal sector and seek explanations for the situation and developments. In the report linked to a theme of social sustainability, Nilsson [31] concluded that the absence of a clear definition of social sustainability opens up for different interpretations that give the concept different meanings in practice. Further, the author noted that most municipal operations seem to be a part of the work with social sustainability but that the "work of social sustainability and the work with traditional 
municipal activities are difficult to distinguish" [31] (p. 44). Consequently, the report concluded, "It does not seem entirely easy to work towards something you neither really know what it is nor can follow up and see the result of" [30] (p. 44) and, in line with Woodcraft [25], called for further research on how work with social sustainability can be made clearer.

To that end, to develop appropriate strategic support and to strategically improve work regarding social sustainability within municipal administrations, it is arguably vital to have an overall understanding of (1) what social sustainability implies [33] and (2) how work is organized today from a strategic sustainability perspective. To our knowledge, this is underresearched in the municipal context. Therefore, the aim of our research was to understand how municipalities, specifically Swedish ones in the eco-municipalities' network (SEKOM), understand and strategically organize their work with social sustainability and to find best practices.

\section{Material and Methods}

To address the aim of our research, we conducted a survey among 21 Swedish ecomunicipalities (see Figure 1) and four follow-up, semi-structured interviews. In support of our study, we used the Framework for strategic sustainable development (FSSD), which is a unifying framework developed to support planning in complex systems.

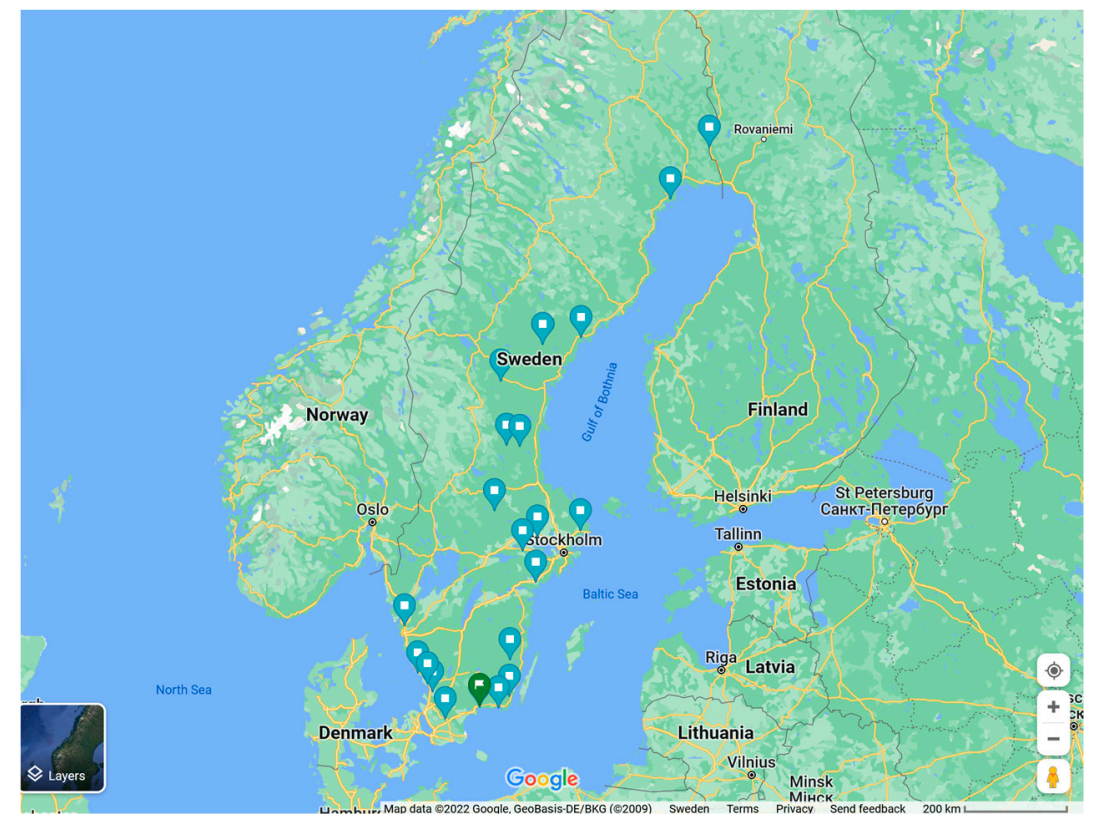

Figure 1. Municipalities that responded to the survey [34].

Below, the FSSD is briefly presented, followed by a description of the survey and interview procedure

\subsection{The Framework for Strategic Sustainable Development (FSSD)}

Acknowledging the systemic sustainability challenge, and the need for many actors to collaborate and be innovative together, the need of a common language for strategic sustainable development was recognized by a group of scientists in the early 1990s [35]. Since then, the FSSD has been developed in a consensus and learning process between scientists and practitioners [19]. Two of the main features of the FSSD were essential in this study to structure data; these are elaborated below. 


\subsubsection{A Five-Level Model for Planning in Complex Systems}

In order to plan strategically, it is important to agree upon the system (level 1) that is to be planned within, before defining success (level 2) within that system. Once success is defined, strategic guidelines (level 3) can be used for the selection and prioritization of actions (level 4). All four of these levels can be supported with various concepts, methods, and tools or other forms of support (level 5) $[19,36]$. Table 1 describes the five levels in the context of strategic sustainable development.

Table 1. Five-level model of the Framework for Strategic Sustainable Development (reprinted from Mesquita and Missimer [37] with permission).

\begin{tabular}{cl}
\hline Level Name & Description \\
\hline The System level & $\begin{array}{l}\text { describes the overall major functioning of the system; in } \\
\text { the case of sustainability, the organization within the } \\
\text { human society within the biosphere. }\end{array}$ \\
\hline The Success level & $\begin{array}{l}\text { includes the definition of the vision, bounded by basic } \\
\text { sustainability principles. }\end{array}$ \\
\hline \multirow{2}{*}{ The Strategic guidelines' level } & $\begin{array}{l}\text { specifies guidelines for how to approach the } \\
\text { principle-framed vision strategically, in an economically } \\
\text { viable, step-by-step approach. }\end{array}$ \\
\hline The Actions level & $\begin{array}{l}\text { comprises everything done in concrete terms, the actions } \\
\text { that were prioritized into a strategic plan. }\end{array}$ \\
\hline The Tools level & $\begin{array}{l}\text { includes concepts, methods, and tools and other forms } \\
\text { of support that are often required for decision support, } \\
\text { monitoring, and disclosures of the actions to ensure they } \\
\text { are chosen in line with the strategic guidelines to arrive } \\
\text { step-by-step at the defined success in the system. }\end{array}$ \\
\hline
\end{tabular}

\subsubsection{A Principled Definition of Sustainability}

The FSSD makes use of eight sustainability principles, three of them about the ecological system and five of them about the social system [19]. They are designed for "backcasting" from a principle-framed vision, to act as boundary conditions for sustainable solutions [38].

The social dimension of the FSSD is built on a complex-adaptive systems' understanding of human social systems and the mechanisms that destroy this social web [33]. By re-framing the mechanisms of destruction as design constraints and declaring these as success or the goal, the approach can support organizations at all levels to strategically contribute to sustainability. The Social Sustainability Principles (SSPs) of the FSSD state that, in a socially sustainable society, people are not subject to structural obstacles to (1) health, (2) influence, (3) competence, (4) impartiality, and (5) meaning making. Structural obstacles here refer to social constructions, political, economic, and cultural, that are firmly established in society and upheld by those with power. Due to various kinds of dependencies and other factors, such obstacles are difficult or impossible to overcome or avoid for those affected by them. Since we were interested in understanding how municipalities work with social sustainability, we here present only the principles related to the social system.

The FSSD was a suitable framework for this study as:

- It is intended for strategic sustainability planning, which is precisely what we wanted to study: how the municipalities engage in this work strategically

- It provides an all-encompassing, science-based, and unifying definition of social sustainability, thus allowing us to structure all social sustainability issues that might be brought up by the municipalities

- It provides a common language, in this case one that the participants were partially already familiar with (see below). 


\subsection{Surveys}

In a first step, we designed a survey that was sent via e-mail through the office coordinator of the eco-municipality network in Sweden (SEKOM) to key contacts for all members. Existing research collaboration enabled a smooth distribution, which was one reason for the choice of this network. The fact that SEKOM is the only eco-municipality network in Sweden, has worked with the principled definition of sustainability of the FSSD since the early 1990s, and has adopted it as their official definition was another reason for the choice of focus. SEKOM currently has 110 municipalities and regions as members; approximately half of them are active according to the network's office [39]. 'Adoption' of the sustainability principles means that this must be documented officially at the municipal board level. However, in many SEKOM municipalities this is more of an overall political statement rather than a concrete way of working with sustainability.

The survey was sent in mid-September 2019 with a time frame of 2 weeks, which was extended upon request until mid-October 2019. A total of 25 people responded, representing 21 municipalities; four municipalities had two people answering. Respondents were first asked about their social sustainability associations off the tops of their heads (without prompting by us). The survey inquired about how municipalities currently think about social sustainability, which themes they work on, and what goals they have in this regard. It further asked who in their organization works with social sustainability matters and which tools they employ in the work. In the second part, we wanted to introduce the established social sustainability definition of the FSSD as a means to have them reflect on their initial responses, to see whether that prompted any more insights and if they would change their scope. Overall, the design of the questions was guided by the five-level model of the FSSD (see Table 2). The survey was structured with the questions in black first, followed by the (re-)introduction of the FSSD social sustainability approach and the questions in blue.

The desired outcome from the analysis was a structure that could visualize municipalities' social sustainability work and also display similarities and differences between the municipalities. After capturing all answers from the online survey tool, they were structured in full [40] into the five FSSD dimensions (in an Excel document), with sub-categories specifically for the systems level (see detailed area of interest in Table 2 above). This initial structuring exercise was done since answers to particular dimensions could be present in answer to any question. Questions in the second part of the survey (where the SSPs were introduced) were specifically marked to provide a foundation for overall comparison and analysis.

Next, all the FSSD structured answers were analyzed, again inductively applying open coding [41] to find themes within each dimension. The software Atlas.ti for qualitative data analysis supported us in keeping a consistent coding of quotes between the different ways of expressing scope, goals, common actions, tools, and ways of working in municipalities. For example, the notion of working with 'inclusion' can be expressed as both 'inclusion of people' or 'exclusion should decrease'. Additionally, the second round of coding also gave an overview and understanding of the variation and frequency of the different aspects between the municipalities: type of positions/structures for collaboration, focus areas (scope), goals, etc. Given this study applies a qualitative analysis method, the number of different aspects/quotes was considered statistically but is compiled in the result section to give a further overview of municipalities' social sustainability work. The survey was in Swedish, which made it natural for the Swedish-speaking author to take on the main part of the initial coding with the aim to find consistent themes from the quotes and translate into English. We had regular meetings to discuss the procedure, emerging codes, and potential interpretations of the data. For the subsequent step of merging the specific into the more general, the other author took the main responsibility, however, keeping up meetings to discuss the results and how to visualize them. 
Table 2. Survey questions according to FSSD Level.

\begin{tabular}{|c|c|c|}
\hline FSSD Level & Detailed Area of Interest & Survey Questions \\
\hline \multirow[t]{2}{*}{ SYSTEM } & $\begin{array}{l}\text { System boundaries: the scope of } \\
\text { social } \\
\text { sustainability work }\end{array}$ & $\begin{array}{l}\text { - When you think of social sustainability for your } \\
\text { municipality, what do you think of then What are the } \\
\text { questions/themes you/they work with? } \\
\text { Given the approach described above, would you add } \\
\text { any other aspects to what the term social sustainability } \\
\text { means or implies for your municipality? } \\
\text { - What are the issues/themes you/they work with? }\end{array}$ \\
\hline & $\begin{array}{c}\text { How is work structured? } \\
\quad \text { Overall } \\
\text { Positions/structures/collaboration }\end{array}$ & $\begin{array}{l}\text { - Who (name, role/function, e-mail address) in your } \\
\text { municipality works with social sustainability? } \\
\text { - What is your/their title? } \\
\text { Is there anyone in your municipality who works (name, } \\
\text { role/ function, e-mail address) with questions regarding } \\
\text { health, influence, competence, impartiality (equal } \\
\text { treatment) and meaning-making? }\end{array}$ \\
\hline SUCCESS & Vision and goals mentioned & $\begin{array}{l}\text { - What are your/their goals in this area? } \\
\text { - First, how familiar are you with this definition? Scale: } \\
\text { - } \quad \text { What are your/their goals in these areas? }\end{array}$ \\
\hline $\begin{array}{l}\text { STRATEGIC } \\
\text { GUIDELINES }\end{array}$ & $\begin{array}{l}\text { What guides strategic work and } \\
\text { decision? }\end{array}$ & $\begin{array}{l}\text { - What are your/their mandates? } \\
\text { - If relevant, how do you work to collaborate on the } \\
\text { above-mentioned issues/areas? }\end{array}$ \\
\hline ACTIONS & Examples & $\begin{array}{l}\text { - What measures do you/they implement? } \\
\text { - What measures do you/they implement? }\end{array}$ \\
\hline TOOLS & Examples & $\begin{array}{l}\text { - } \quad \text { Do you use any special tools to carry out the work? } \\
\text { - } \quad \text { Do you use any special tools to carry out the work? }\end{array}$ \\
\hline
\end{tabular}

\subsection{Semi-Structured Interviews}

In a second step, we interviewed representatives of municipalities that had come out as the most organized in the survey. Since our aim was to understand how municipalities organize their social sustainability work in practice, but also what best practice may look like and how all municipalities might be supported to do this work more strategically, it made sense to deepen our understanding with best-in-class examples. As a foundation for interview selection, a summary of results regarding municipalities' reported goals, collaboration structures, and what guides strategic work and decision was done. While all respondents could provide information about the scope of the work, positions, and at least themes for what success looks like, fewer (16 of 21) provided specific goals for social sustainability. Even fewer gave examples of specific structures for collaboration (internally and/or externally) and specific procedures, or guidelines, for strategic work and decision making (10 of 21, respectively) The five municipalities that reported on all dimensions of strategic work were evaluated on whether there were signs of coordination and clarity in their social sustainability work, for example, if there were alignments between how they structure work, scope, and goals and if there were collaborative structures or platforms in place such as those that have been emphasized as vital by several scholars, e.g., [29,31] This analysis resulted in a selection of three municipalities with one or two interviewees in each municipality.

The focus of the semi-structured interviews was primarily on gaining more details regarding the systems and strategic guidelines' dimensions of the FSSD, specifically on 
how internal and external work is structured and what guides strategic work and decisions. Survey results were sent to each interviewee prior to the interview, and interview questions were built upon the results of each municipality, thus making them case specific. However, some overarching questions were formulated:

- Where in the organization do people with responsibility for social sustainability sit?

- Are there any established routines for coordination and collaboration? Which ones?

- Are any formal or informal structures that you think would enhance your work missing?

- How do you ensure alignment between scope, goals, and structuring of work?

- How are you working with external actors? What is working? What could be better?

Interviews were done online and lasted between 30 and $45 \mathrm{~min}$. All interviews were tape-recorded and transcribed verbatim. Data from the interview transcripts were structured and analyzed in relation to the interview questions and summarized and illustrated in a descriptive text (see below).

\section{Results}

A total of 21 municipalities responded to the survey. In most cases, one person responded as a representative from the municipality, but in some cases, there were two. Table 3 gives a summary of the results and an overview of the quantitative answers as well as selected qualitative ones for all municipalities.

One first observation was that no real patterns could be deducted from this highlevel overview and that a deeper qualitative analysis was required to gain meaningful understanding of each municipality and any potential patterns across them.

In the following, results from the survey are first presented in terms of what municipalities are doing in relation to social sustainability, what they consider as the scope of social sustainability, how success is described, what guides strategic action, what they do in practice (actions), and what tools are in use. Next, the results from the interviews are presented and give the perspective of how municipalities operate at the forefront from a strategic perspective structure and conduct their work.

From an overall perspective, several of the responding municipalities specifically suggested that social sustainability is an important foundation and integrated in all activities. The diversity and spread of answers also supported this even if it was not always specifically formulated as such in the responses. Many suggested that collaboration and networking is key, that social sustainability work is done best together, and have ambitions to coordinate social sustainability work more. They acknowledged the immensity of the challenge and that long-term change (even for future generations) is needed, which requires strong leadership.

However, the coordination was a matter of great variation between the responding municipalities. While the municipalities of Norrtälje and Örnsköldsvik expressed relatively developed platforms and structures for collaboration, others revealed that there is no one specifically appointed to work with social sustainability issues but that work still happens in different places. 
Table 3. Summary of results.

\begin{tabular}{|c|c|c|c|c|c|c|c|c|}
\hline ID \# & Pop Size & Themes & Pos/Stru & Respondent & Vision & Strat. G. & Actions & Tools \\
\hline 1 & 103,800 & 7 & 2 & - $\quad$ Growth strategist & - $\quad$ None & Yes & 4 & 2 \\
\hline 2 & 78,500 & 8 & 3 & $\begin{array}{l}\text { - Social Strategist } \\
\text { public health }\end{array}$ & $\begin{array}{l}\text { - Overarching vision }+ \\
\text { specific goals in some } \\
\text { areas }\end{array}$ & Yes & 12 & 5 \\
\hline 3 & 66,500 & 14 & 5 & $\begin{array}{l}\text { - } \quad \begin{array}{l}\text { Public health } \\
\text { strategist }\end{array}\end{array}$ & - $\quad$ medium-level goals & Yes & 4 & 3 \\
\hline 4 & 63,700 & 12 & 2 & - $\quad$ Head of safety & $\begin{array}{l}\text { - high level in various } \\
\text { areas }\end{array}$ & Yes & 0 & 2 \\
\hline 5 & 57,000 & 17 & 6 & $\begin{array}{l}\text { - } \quad \text { Security coordinator } \\
\text { - Coordinator social } \\
\text { issues }\end{array}$ & $\begin{array}{l}\text { - } \quad \text { high level in various } \\
\text { areas }\end{array}$ & No & 8 & 2 \\
\hline 6 & 55,800 & 16 & 3 & $\begin{array}{l}\text { Head of the public } \\
\text { health and } \\
\text { competence unit } \\
\text { Development } \\
\text { strategist }\end{array}$ & $\begin{array}{l}\text { - high level and focus on } \\
\text { health }\end{array}$ & Yes & 16 & 15 \\
\hline 7 & 47,000 & 5 & 1 & $\begin{array}{l}\text { Development } \\
\text { manager Public } \\
\text { health }\end{array}$ & $\begin{array}{l}\text { overarching }+ \text { specific } \\
\text { goals in some areas }\end{array}$ & No & 3 & 4 \\
\hline 8 & 46,000 & 3 & 5 & $\begin{array}{l}\text { - Environmental } \\
\text { strategist }\end{array}$ & - $\quad$ Agenda 2030 goals & Yes & 0 & 3 \\
\hline 9 & 46,000 & 10 & 2 & $\begin{array}{l}\text { Development } \\
\text { manager social } \\
\text { sustainability }\end{array}$ & $\begin{array}{l}\text { Agenda } 2030+\text { Human } \\
\text { rights }+ \text { specific goals for } \\
\text { health }\end{array}$ & Yes & 5 & 2 \\
\hline 10 & 32,400 & 9 & 10 & $\begin{array}{l}\text { Public health } \\
\text { strategist + Leisure } \\
\text { consultant }\end{array}$ & $\begin{array}{l}\text { overarching }+ \text { high level } \\
\text { on some areas }+ \text { some } \\
\text { more specific }\end{array}$ & Yes & 10 & 3 \\
\hline 11 & 26,800 & 5 & 7 & $\begin{array}{l}\text { - } \quad \text { Public health } \\
\text { strategist }\end{array}$ & $\begin{array}{l}\text { - Specific goals for many } \\
\text { areas }\end{array}$ & Yes & 6 & 1 \\
\hline 12 & 25,900 & 2 & 1 & $\begin{array}{l}\text { Manager at strategy } \\
\text { unit }\end{array}$ & - $\quad$ Specific area & No & 2 & 0 \\
\hline 13 & 18,900 & 4 & 2 & 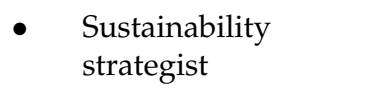 & $\begin{array}{l}\text { - } \quad \text { overarching + Agenda } \\
2030 \text { goals }\end{array}$ & No & 2 & 1 \\
\hline
\end{tabular}


Table 3. Cont.

\begin{tabular}{|c|c|c|c|c|c|c|c|c|}
\hline ID \# & Pop Size & Themes & Pos/Struc & Respondent & Vision & Strat. G. & Actions & Tools \\
\hline 14 & 16,800 & 2 & 3 & $\begin{array}{l}\text { Integration } \\
\text { coordinator }\end{array}$ & - $\quad$ high level & No & 3 & 1 \\
\hline 15 & 11,700 & 13 & 3 & $\begin{array}{l}\text { Public health } \\
\text { coordinator }\end{array}$ & $\begin{array}{l}\text { - high-level goals for some } \\
\text { areas }\end{array}$ & Yes & 11 & 4 \\
\hline 16 & 10,900 & 15 & 7 & $\begin{array}{ll}\text { - } & \text { Environmental } \\
\text { strategist }+ \text { Youth } \\
\text { coordinator }\end{array}$ & $\begin{array}{l}\text { - high-level goals on many } \\
\text { areas }\end{array}$ & No & 1 & 0 \\
\hline 17 & 10,700 & 13 & 1 & - $\quad$ Municipal strategist & $\begin{array}{l}\text { overarching + Agenda } \\
2030 \text { goals + specific } \\
\text { goals on influence and } \\
\text { participation }\end{array}$ & Yes & 5 & 2 \\
\hline 18 & 9200 & 3 & 1 & 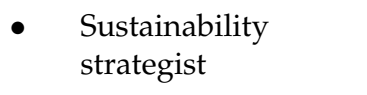 & - $\quad$ overarching & No & 2 & 1 \\
\hline 19 & 7100 & 4 & 2 & $\begin{array}{l}\text { - Climate and Energy } \\
\text { coordinator }\end{array}$ & - $\quad$ none & No & 4 & 0 \\
\hline 20 & 5700 & 5 & 1 & $\begin{array}{l}\text { - Public health } \\
\text { coordinator }\end{array}$ & $\begin{array}{l}\text { - } \quad \text { specific goals for some } \\
\text { areas }\end{array}$ & No & 1 & 1 \\
\hline 21 & 4200 & 4 & 1 & $\begin{array}{l}\text { Equality and public } \\
\text { health coordinator }\end{array}$ & - $\quad$ high-level goals & No & 4 & 0 \\
\hline
\end{tabular}

\subsection{The Scope of Social Sustainability Work (System Level)}

The scope was revealed by asking what issues or themes the respondents' municipalities work with related to social sustainability. The average number of themes mentioned per municipality was 8.1, with 2 being the lowest and 17 being the highest number. A vast diversity and spread of themes became clear, which is illustrated by the number of words in Figure 2. In total, 105 unique themes were mentioned across 171 quotes regarding scope. These 105 were then clustered into 35 more general themes. For example, terms such as 'The health of elderly', 'Equal health', and 'Mental health' were clustered with 'Public health' to form a general theme. The top 10 general themes that emerged from the data were Public Health (17 mentions), Equality (12), Safety (10), Participation (9), Influence (9), ANDTG (Alcohol, Narcotics, Drugs, Tobacco, and Gaming) (8), Domestic and Family violence (8), Integration (8), Children and Youth (7), and Education and Skill Development as well as Democracy and, finally, Employment, Working life, and Livelihood (all with 6 mentions). Figure 2 shows all 35 themes (the number of mentions being indicated by the font size in the image). 


\section{Democracy}

Well-being + Quality of Life

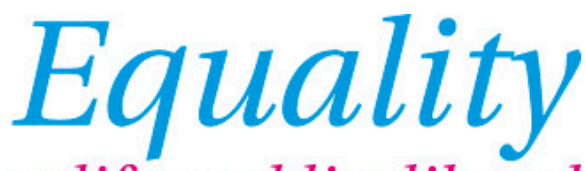

Employment, working life and livelihood

Saftey - Integration

$\underset{\text { Social services }}{\text { Domestic + family violence }}$

\section{Public}

Influence

Agenda 2030

ANDTG

Education + Skill Development

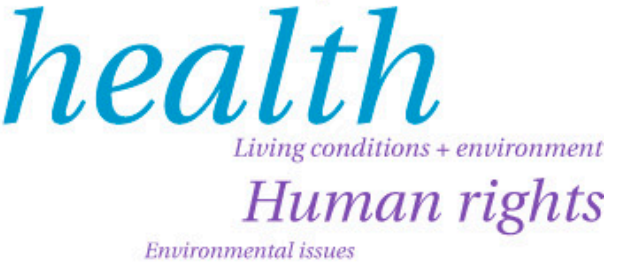

Children + Youth

Crime prevention

Function variation

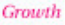

Growth

Citians dielogter

Elderly

Urban planning

Diversity

Figure 2. Scope of social sustainability in municipalities.

\subsection{Organization and Structure of Work (System Level)}

The diversity of work and approaches becomes especially visible when reviewing the roles (positions) and structures mentioned in relation to social sustainability. From the 21 responding municipalities, 55 different positions and 10 structures were mentioned. Most respondents (10) listed one to three positions or structures; however, some (two) municipalities listed up to 11 positions/structures. When prompted with questions in relation to the social sustainability principles, a majority of the respondents mentioned additional structures and positions compared to their original answers.

When analyzed by theme (see Table 4), one can immediately see that the focus on public health was also present in where the (perceived) responsibility for social sustainability lies. However, the rest of the mentions in the table do not match the mentions of themes discussed above. Equality, for example, ranked second under scope above, but was only mentioned once directly in the positions and structures and only in connection to Public Health (Equality + Public Health coordinator). Table 5 presents the positions and structures by activity. However, when combined with the full position, e.g., ANTG coordinator, there were not very many duplicates. The position 'Public health planner' was most common, with five reports, followed by three 'Public health strategists' and two 'Sustainability strategists' and 'Project leaders for mental health', respectively. Most mentioned their own, specific names for positions and structures. Social sustainability strategist and manager only received one mention each. 
Table 4. Positions and structures by theme.

\begin{tabular}{cc}
\hline Theme & Mentions \\
\hline Public Health & 21 \\
\hline General Sustainability + Agenda 2030 & 5 \\
\hline Development + Growth & 5 \\
\hline Safety + Security + Crime Prevention & 5 \\
\hline Integration & 4 \\
\hline Social Services & 4 \\
\hline General Strategy Unit & 3 \\
\hline Social Sustainability & 3 \\
\hline Culture + Leisure & 3 \\
\hline Environmental + Climate and Energy & 3 \\
\hline Anti-violence & 2 \\
\hline Children and Youth & 2 \\
\hline Human Resources & 2 \\
\hline Democracy & 2 \\
\hline Family + Education & 2 \\
\hline Function Rights + Accessibility & 2 \\
\hline Mother tongue responsible & 1 \\
\hline ANDT & 1 \\
\hline
\end{tabular}

\subsection{Themes of Visions and Goals for Social Sustainability (Success Level)}

As a logical consequence of the scope of social sustainability work and who is working with it, 'Good public health' and other goal formulations with health included were the most common goals and visions mentioned in the survey. Next came goals around 'equality' and, close thereafter, 'influence'-related goals. Good living environments and safety were also commonly mentioned by respondents, as well as a society built upon collaboration, such as Örnsköldsvik's one-liner 'We build best together'. In general, most respondents listed their goals as increasing or decreasing the themes of the scope, e.g., increase equality, decrease crime, etc., or even just the general theme, e.g., Human Rights, Agenda 2030, or "Good Public Health". Only a few responded with more ambitious statements, such as "A municipality for all" or "We will become Sweden's safest municipality". No one listed a specific target such as gender distribution in leadership positions or percentage of people with chronic diseases.

Table 5. Positions and structures by kind.

\begin{tabular}{cc}
\hline Activity & Mentions \\
\hline Strategist & 27 \\
\hline Coordinator & 14 \\
\hline Head of & 8 \\
\hline Developer & 6 \\
\hline Manager & 6 \\
\hline Department & 5 \\
\hline Project leader & 4 \\
\hline
\end{tabular}


Table 5. Cont.

\begin{tabular}{cc}
\hline Activity & Mentions \\
\hline Consultant & 3 \\
\hline Working group & 2 \\
\hline Responsible & 2 \\
\hline $\begin{array}{c}\text { Strategic+operative collaboration groups for } \\
\text { sub-areas }\end{array}$ & 1 \\
\hline Forum for sust. issues & 1 \\
\hline Council & 1 \\
\hline Working group with the county admin. board & 1 \\
\hline Expert official & 1 \\
\hline Investigator & 1 \\
\hline General staff & 1 \\
\hline
\end{tabular}

\subsection{Strategic Guidelines (Level)}

In terms of how strategic work and decision making are guided, several answers spoke to the work being goal based and that different policy documents, plans, and strategies are developed to hold together the work for different areas and themes, such as policies for public or equal health. Based on the documents, missions from politicians set the agenda. One municipality, however, said that it does not have any defined goals that it steers towards since that could rather limit the work given the complexity of social sustainability work. Instead, social relations are key and the 'good sustainable meeting' provides a foundation for process management:

"It is the contact between us and our customers, residents and users that creates the value of our services. How the residents experience the meeting is crucial for their experience of (our) municipality. Something that is also the basis for control via processes".

A few other municipalities did also emphasize the need to put the individual in focus, although at the same time acknowledging overarching goals. Agenda 2030 was referred to by some municipalities as a guide for their work. In addition, multi-level management was mentioned as something that affects strategic work and decision making in terms of national laws for different areas of activity that come into play, such as the Education Act, the Social Services Act, and the Health Care Act. While collaboration and co-action were brought up by several of the respondents, a few also revealed that they can do more and better to bridge the silos between departments and focus areas.

\subsection{What Is Being Done in Practice (Action Level)}

A total of 88 unique actions were given by respondents. The mentions ranged from very high-level actions, such as coordinate with external actors, to very specific, such as coordinate rainbow week, create a digital platform, offer free holiday activities for children and youth, or work with fall accidents among the elderly, etc. Clustered into themes, but still fairly close to the original wording, the actions are shown in Table 6. 
Table 6. List of actions mentioned more than once.

\begin{tabular}{cccc}
\hline Action & $\#$ & Action & $\#$ \\
\hline Inform and educate/ Raise knowledge & 10 & Collaborate with associations & 3 \\
\hline Conduct surveys + investigations & 8 & Coordinate with external actors & 3 \\
\hline Internal consulting and support & 7 & Develop and apply assessment tools & 3 \\
\hline Citizen dialogues & 6 & $\begin{array}{c}\text { Overall planning, steering, and } \\
\text { follow-up, e.g., the Comprehensive plan }\end{array}$ & 3 \\
\hline Work for (e.g., inclusion) & 5 & Preventive work & 3 \\
\hline $\begin{array}{c}\text { Coordinate work in a particular area } \\
\text { (e.g., mental health, crime prevention) }\end{array}$ & 4 & Develop and coordinate policy & 2 \\
\hline $\begin{array}{c}\text { Develop steering documents, strategic } \\
\text { plan, action plans, and budget }\end{array}$ & 4 & $\begin{array}{c}\text { Development of places for spontaneous } \\
\text { activity and meetings }\end{array}$ & 2 \\
\hline $\begin{array}{c}\text { Develop support for citizens } \\
\text { (e.g., elderly, parents) }\end{array}$ & 4 & Participate in national networks & 2 \\
\hline Conduct follow-ups & 4 & Revise strategies and programs & 2 \\
\hline
\end{tabular}

In addition, adopt goals etc. to the local level, contribute to the regional development strategy, listen to the needs among municipal operations, pilot projects, procurement, relationship building, conversations and anchoring work, research collaboration, societal planning, support operations in prioritization, support for a broad and active association life, work with Agenda 2030, and workshops were all mentioned once. Figure 3 gives a visual representation of the nature of the work and highlights that the actions are most often of developmental and planning as well as coordinative and supporting natures and that information distribution and communication also are major focus areas.

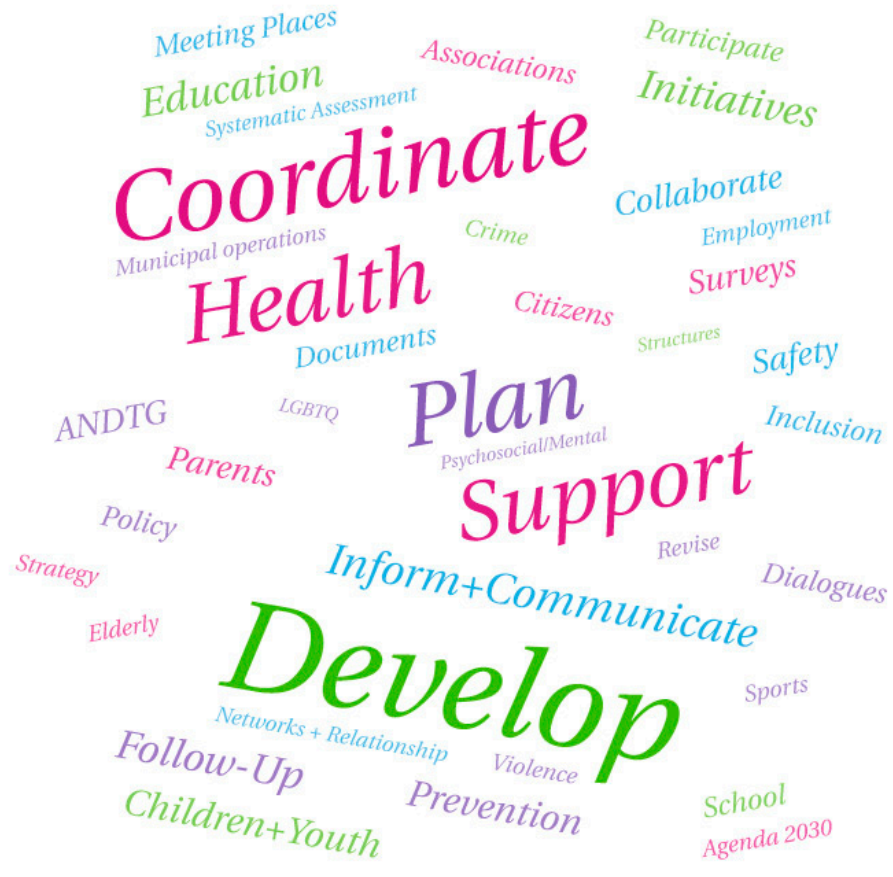

Figure 3. Main emphasis in the category of actions.

\subsection{What Tools Are in Use}

Following the type of actions provided, examples of tools were related to:

- Collaboration, where various councils, working groups, and networks were mentioned as well as continues dialogue with various stakeholders. 
- Various theories and models such as the participation ladder, the SKR toolbox, process tools, and evidence-based methods.

- Assessment and analysis, such as SWOT.

- Utilizing existing and creating new declarations, policies, and laws.

- Planning, e.g., the equal treatment plan in schools, the HBTQ strategy and action plan, etc.

- Visions and goals to drive the processes.

- Indicators' sets to follow up in a measurable way.

- Mindset: One respondent mentioned keeping a level head as a way to navigate the complexity.

- Employees: One respondent mentioned the employees as the main asset to implement any work in this area.

\subsection{Best Practice Interviews}

Three municipalities were selected for interviews: Bollnäs (ID \# 11), Norrtälje (ID \# 4), and Örnsköldsvik (ID \# 6). They are presented here with the aim to provide nuance to how municipalities organize social sustainability work.

\subsubsection{Bollnäs}

The municipality of Bollnäs has about 26,800 inhabitants and a lot of rural area and is located in central Sweden about 280 kilometers north of Stockholm. Table 7 lists a summary of survey and interview answers regarding its strategic social sustainability work.

Table 7. How work with social sustainability is organized in Bollnäs.

\begin{tabular}{cl}
\hline Level & \multicolumn{1}{c}{ Details } \\
\hline & Scope: ANDGT, Children's rights, Democracy, Equality, Gender \\
equality, Human rights, Influence, Job opportunities, Mental \\
health, Public health, Security work/violence prevention, and \\
Well-being \\
Structures: Accessibility coordinator, Anti-violence strategist, \\
Democracy coordinator (influence), Integration strategist, \\
Investigator (influence), Leisure consultant, Public health \\
strategist (health, influence), Accessibility council, Advisory body \\
for pensioners, Council for public health, Local association \\
network, Local crime prevention council, Steering group public \\
health and security (Youth council), and Participation in regional \\
and national networks for public health
\end{tabular}

Overall, the municipal administration aims to link issues under the social sustainability umbrella through common goal structures. The interviewee (the public health strategist) confirmed that social sustainability work is done throughout the whole administration, for example, in schools, social services, and elderly care. However, employees with strategic or coordinative roles are placed at the municipal board administration, which reports directly to the Municipal board (politicians). Thereby, strategists and coordinators have direct contact with the top management of the municipal administration. Seven different positions with strategic and coordinative roles were mentioned (see Table 7). In addition to proximity to decision makers, another benefit of this placement, according to the interviewee, is the 
everyday contact between colleagues, being able to easily share ideas and thoughts with colleagues with similar positions. Through the questions related to each social sustainability principle, the municipality reported that there are roles or units directly linked to work with issues connected to health and influence. For the latter, for example, there is a 'democracy coordinator'. In terms of competence, these issues are addressed differently for different departments, and no specific work towards the local community was mentioned. Further, no structures for impartiality or meaning making were specified.

In terms of structures that support coordination and collaboration, the interviewee mentioned several internal and external platforms and networks. Internally, there is a council for public health with politicians from all political municipal committees and a steering group for public health and security with representatives from all departments and other societal actors such as the police, larger independent schools, and the municipal housing company. In addition, there are three other councils (for Youth and Elderly and one linked to functional rights) with politicians represented as well as important actors from the local society.

To guide strategic work, decisions, and collaboration, a new program for social sustainability and public health is under development and will be the guiding document for the steering group for public health and security. The aim of this program is to combine or link other plans and policies related to social sustainability, and it will utilize the SSPs (social sustainability principles) as a frame. More specifically, activities and impact measures are based on goals of the municipal council and the municipal board. These goals are to be reflected in the new program and reflected in scorecards for the municipal operations.

Strategic activities relate to providing information and raising knowledge. Internally, the strategists and coordinators act as advisors and experts towards politicians and the municipal administration. Externally, they, for example, plan and conduct citizens' dialogues (including youth) in support for policy, conduct and administer surveys, and participate in parent meetings. While tools can be many and changing, communication was specifically highlighted.

While there is insight and ambition among many politicians and administrative leaders to take a holistic approach and work long term with social sustainability, there are still barriers to overcome. For example, operations are drowning in their own work and (silo) focus. A lot of responsibility is put on municipalities from national directives, but not enough resources are allocated to do the work accordingly. There is also a concern about how the 2022 year's election will affect the newly produced but not yet determined program for social sustainability and public health.

Not yet in place, but planned for, is a complementary forum for public health and security where civil society and other authorities can also participate. The ambition is to meet in the extended forum once a year to have a reconciliation where all actors' competence and their target groups' perspectives are considered. Through the dialogue, new temporary groups can form based on contemporary needs. Responding to the interview question of how alignment between scope, goals, and the structuring of work is assured, the interviewee said that although many important aspects are in place, everyone with any responsibility needs to adopt and 'breathe' the new program. The aim is to find appropriate approaches to attract people from all operations who have special interest in dealing with social sustainability issues and can report back to their respective steering groups. So far, there have been goals and ambitions available in different policy documents, but these have usually not been considered to a sufficient extent. Asked what is required to reach the ambitions, the interviewee admitted that, unfortunately, often signs of unsustainability, such as the increasing gang crime and reports of mental illness, need to be visible for action to happen.

\subsection{2. Örnsköldsvik}

Örnsköldsvik municipality is situated in the northern part of Sweden, $550 \mathrm{~km}$ north of Stockholm, with a population of 55,800 inhabitants. To carry out the tasks a municipality 
has, one rarely works alone according to both interviewees. Still, it is not always clear who has the coordinative responsibility for specific focuses and issues. See Table 8 for an overview of how work is organized in Örnsköldsvik.

Table 8. How work with social sustainability is organized in Örnsköldsvik.

\begin{tabular}{|c|c|}
\hline Level & Details \\
\hline System & $\begin{array}{l}\text { Scope: ADNTG; Function variations; Agenda 2030; Autonomy, } \\
\text { influence, and participation; Competence, knowledge, and } \\
\text { education; Conventions and declarations; Employment, working } \\
\text { life, and livelihood; Environmental policy; Equality; Growth; } \\
\text { Health and lifestyle, Human rights; Legislation; Living and local } \\
\text { environments; Public health; Skills' supply issues; Special mission } \\
\text { regarding men's violence against women } \\
\text { Structures: Business Developer Welfare Administration: } \\
\text { Democracy coordinator; Development strategist; Head of student } \\
\text { health; Head of the public health and competence unit; Human } \\
\text { resources' director; Local collaboration group; Regional } \\
\text { coordination association; Strategic and operative collaboration } \\
\text { groups for sub-areas within the administration; Sustainability } \\
\text { forum for sustainability issues }\end{array}$ \\
\hline Success & $\begin{array}{l}\text { Goals: We build best together; Good to live in and visit } \\
\text { Örnsköldsvik; Conditions for good and equal health for all; To } \\
\text { close the influenceable health gaps; Act for the issues at all } \\
\text { societal levels }\end{array}$ \\
\hline $\begin{array}{c}\text { Strategic } \\
\text { Guidelines }\end{array}$ & $\begin{array}{l}\text { What guides strategic work and decisions? Work through } \\
\text { multi-level management, collaboration, and co-action. Multilevel } \\
\text { management: municipal obligation to comply with laws + } \\
\text { political governance. Actions should have effect for the } \\
\text { individual. Work is adapted to each issue or focus area. }\end{array}$ \\
\hline
\end{tabular}

Within the municipal administration, cross-municipal and strategic responsibilities are coordinated from the public health and competence unit, which is located at the municipal management administration and answers to the municipal board. One interviewee, however, emphasized that despite distribution across multiple departments it is important that the responsibility for coordination linked to specific work also lies with each department.

The survey answers underlined this spread of coordinative responsibility. For example, health is connected to most operations but takes different forms, such as the care of employees at the human resources' department, students' health, community planning and health promotion, social services, and culture and leisure. Additionally, in terms of competence, shared responsibility becomes obvious. The education administration covers from 1-year-old children up to adult education, while the public health and competence unit deals with post-secondary education, research collaboration, and inhabitants' need for competence. Further, the human resources' department is responsible for staff competence and competence supply issues, while each manager is responsible for having development talks (including skills' development) with their employees. At the welfare unit, assessments of work ability and support needed to enter the labor market are also made. Both interviewees described the ambition for influence and impartiality aspects to be integrated into all activities and that the work looks different depending on operations. They are municipality-wide assignments, but, for influence, for example, the municipality has a number of councils (including councils for accessibility and participation) and works for active participation in elections. Furthermore, the education administration works, for example, with impartiality in connection with students. Regarding meaning making, interviewee 1 said they have talked about a sense of context for a long time and interviewee 2 expressed that these questions are closely related to the welfare administration's assignment according to the Social Services Act. 
Addressing the complexity of social sustainability work in the municipality, one of the interviewees described it as working with, and understanding, many different layers and connections. This is, in turn, the main job for the employees at the public health and competence unit, to continuously take a helicopter perspective, make sense of the web of issues and assignments, to inform policy, and provide a clear basis for decision making. The roles presented in Table 5 are positions at this centrally placed unit and important heads of departments who also have coordinative responsibility in relation to their respective assignments.

Internally, Örnsköldsvik has appointed strategic and operative collaboration groups for different sub-areas, e.g., a clearly stated mission to the administrations for welfare, culture and leisure, education, and social services to collaborate around children and young people. Similar collaborations exist for mental illness and gender equality, as well as crime prevention work. For overall sustainability issues, there is a newly (2018) established Sustainability Forum, which is composed of committee presidents, heads of administration, and coordinators within the municipal administration. Interviewee 1 emphasized how the work must not be too rigid. In a new pilot project, the municipality will work innovatively to involve citizens through so-called 'Together contracts' supported through The Swedish Association of Local Authorities and Regions [30] (SALAR). The goal is for elected representatives, officials, and citizens together to develop solutions to local problems and for this to be formulated as a social contract between the various actors.

Collaboration is key and, in addition to working with local actors, Örnsköldsvik has a long tradition of collaborating across borders with other municipalities and regions, for example, through the 'Coordination association' at a regional level (Samordningsförbundet) [42] and by being a 'model municipality' within a concept developed by SALAR for municipalities' work with gender equality integration through mutual learning [43]. Collaboration within the geographical municipality is also established through the "Coordination association' and a local collaboration group where the municipality, the County Council, the Swedish Social Insurance Agency [44], the Swedish Public Employment Service [45], and the Police are included and collaborate on preventive and rehabilitative initiatives in the areas of health, work, and livelihoods.

To ensure alignment between scope, goals, and the structuring of work, interviewees referred to the importance of working together and to have continuous dialogues. Policies, such as the sustainability policy and the policy for public health and social sustainability, are formal support. However, the administration must improve how it works with them and better links work to the quality management system for follow-up and development of operations. The equality work is a forerunner in this regard and the municipality has, for example, developed a checklist for integration of an equality perspective in decision making. Reorganizations in recent years have been in support of the social sustainability work. At the same time, work remains. For example, Agenda 2030 and the municipality's overall goals do not align perfectly with the two sustainability policies, and cohesive information and communication both internally and towards inhabitants could improve, e.g., through working more with strategists and coordinators on ecological sustainability.

In addition to the placement of the coordinative unit in the organization, interviewees stated that many other factors have come into play that have been favorable for social sustainability work in Örnsköldsvik, such as declarations and being a model municipality through SALAR. It is also very important that the management is active. As noted above, follow-up and all needed structure and culture for the work is not fully in place yet, but a key success factor is that leaders have ambitions in this regard and declare what result they expect.

\subsubsection{Norrtälje}

Norrtälje is a municipality with 63,700 inhabitants within the region of Stockholm. Table 9 gives an overview of its social sustainability. 
Table 9. How work with social sustainability is organized in Norrtälje.

\begin{tabular}{cl}
\hline Level & \multicolumn{1}{c}{ Details } \\
\hline & Scope: Active senior; Crime prevention; Domestic violence; \\
& Eating habits; Economy; Influence; Integration; Mental health; \\
& Participation; Public health; Welfare; Well-being \\
& Structures: Department 'Safe in Norrtälje kommun' with 11 \\
& employees; Head of department, Field coordinators, Parent \\
& supporters, Public health strategist, Public health coordinator, \\
& Safety coordinator, Local area groups; the TiNk council, The \\
& Municipal management, and the Local Security and Safety \\
& council. \\
& Goals: We will become Sweden's safest municipality; Conditions \\
& for good health on equal terms and good conditions for growing \\
& up and living; Possibility for participation for all; Freedom, future, \\
& and trust; It is easy to live healthily in Norrtälje municipality. \\
\hline Success & What guides strategic work and decisions: A method/system \\
& based on steering, structure, collaboration, and common goals. \\
\hline Strategic &
\end{tabular}

Norrtälje has a clear vision of becoming the safest municipality in Sweden and it has established a department called 'Safe in Norrtälje', which leads, collaborates, and coordinates the preventive security work with the whole internal administration and societal actors, such as the Police, the non-profit sector, and businesses. The department reports directly to the municipal board and has 11 employees with different roles who, in turn, coordinate 15-20 platforms with different municipal operations and local actors. Everyone within the department works strategically and long term with common goals; their assignments are not specifically regulated by law and can, thus, be more flexible and better adapted to their context. A pre-requisite is also that no work is done at an individual level, which means that prevention work can focus on structural problems with the potential to solve the root cause of problems for many. Representatives within the platforms that the department coordinates, on the other hand, are people on both strategic and operational positions, with the latter having direct contact with constituents, children, young people, addicts, and so on.

A mission in 2008, with the aim to review preventive measures and analyze what needed to be done, gave rise to 'Safe in Norrtälje'. Problems such as drug-addicted youths in high school were a starting point, and work was inspired by previous and similar attempts in the Stockholm area and Linköping municipality. Preventive home visits and other interventions were successful, and politicians were willing to invest in the developing philosophy and vision, which eventually became its own department. According to the interviewee, the leadership role is vital to make a system work. It is relatively uncommon to have a manager who leads the work in the realm of social sustainability and is responsible for the crime-prevention strategy. Strategists and coordinators are very important but cannot be held accountable in the same way as a manager can. If development goes in the wrong direction and becomes unsafe, there is a manager who can be held accountable, in the same way as the finance manager has overall responsibility for the finances.

Reflecting on the social sustainability principles, specific structures and positions for health and influence exist similar to how it is described for Örnsköldsvik and Bollnäs. Further, the interviewee described how the human resources' department has responsibility for internal competence development, while the 'Safe in Norrtälje' department works with issues related to equal treatment (impartiality) and meaning making.

The platforms that the department coordinates are vital for the work. Four platforms build the foundation: local area groups, the TiNk council, the municipal management, and the local security and safety council. The work is based on perceived problems, surveys, statistics, etc. The department's role is to be the engine that makes things happen through defining assignments, offering methods, providing support, and creating commitment. 
Among other things, municipal representatives work with the police on a daily basis based on common goals. Twelve police officers are deployed for preventive purposes. Collaborations also exist with the business sector. Overall, the interviewee described a successful method and system based on steering from the municipality's overarching goals and the policies on safety and public health. To that end, structure, collaboration, and common goals guide strategic work and decision making. Goals and actions are integrated into the municipal budget, linked to indicators, and are part of the annual follow-up.

Considering how or when things can go wrong, the interviewee reflected upon on how everything is dependent on human relations and the importance that management and politicians understand and support the work. When key personnel leave their jobs and new people are being introduced, there is always a struggle to align thinking. Work around safety is also always about trust between people; having a bad day at work can quickly turn into unwanted consequences if employees are not aware of their possibly bad behavior towards others. Ideally, the inhabitants would be considered, and consider themselves, as 'colleagues at work' when it comes to security and social sustainability in the municipality.

Good communication is key. Another success factor is to have the courage to put together a department such as 'Safe in Norrtälje', including a manager with a sufficient mandate. It does not become more expensive, rather the opposite, the interviewee reported. Additionally, it is important to work with motivation and inspiration since it is not possible to command and steer people in such a large organization or an entire municipality, for that matter.

\section{Discussion}

In this section we discuss the results, procedures, and limitations of the survey and interviews and relate our findings to a broader sustainability perspective. The overall impression was that most municipalities are very busy doing a lot of things in the social sustainability field, often with very limited resources.

In some ways not surprisingly, and in line with Nilsson [31], our study revealed that social sustainability is integrated into many if not almost all activities in a municipality, from developing policies and plans to providing education (schools), elderly care, and social services. However, as Krause, et al. [4] noted regarding the locus of sustainability responsibility in a US context, our survey also revealed that the way municipalities in the Swedish eco-municipality network think about and work with social sustainability varies widely.

\subsection{Reflections in Relation to Five Levels of the FSSD}

At one end of the scale, municipalities identify social sustainability with one or two existing areas of their work, such as public health and integration. On the other end, some municipalities have visions and work plans spanning multiple areas and departments. Given that our analysis resulted in 105 unique themes and 35 general themes, a relevant consideration is if the municipality that reported the highest number of specific themes (17) misses out on something important. An analysis based on the social sustainability principles indicated that they do, and the use of the principles could support practitioners in identifying a more complete and holistic set of themes. For example, one of the municipalities that reported only two themes for the scope of social sustainability work did that both from a very overarching perspective in terms of 'taking care of the people' and relatively specific, pointing towards the 'reception of new arrivals'. In terms of structure at the more advanced end, the municipal representatives face the complexity of social sustainability work by collaborating extensively across departments and sectors; key leaders are assigned the responsibility to work with social sustainability or the municipality has a designated social sustainability strategist or planner, while acknowledging that everyone in the municipality works with these themes to some extent. In between these two ends, many municipalities have a fairly good understanding of sustainability, but their understanding and existing positions and structures do not always match their goals and focus areas and 
they do not manage to overcome the barriers in the existing structure of the municipality to work more strategically with the issues.

The number of positions and structures mentioned was in no way correlated to how advanced a municipality is in its work. Norrtälje, for example, came out as best in class but named very few positions/structures in the survey. A larger number could simultaneously imply extensive integration and be very positive if combined with extensive collaboration or that the organization is very diffused and inefficient and, thus, probably ineffective. In Norrtälje's case, the work is very centrally and strategically organized, and the main coordinative responsibility lies with a few, who are then tasked to work with others and link people together. In addition, the actual name of the coordinating person did not seem to matter much. Some were named sustainability strategist but. because of their placement within the larger organization. did not have much leverage to do strategic work. Others were called public health coordinator but, because of their placement and overall assignment, held a central position in all social sustainability work.

In terms of vision and goals, these reflected the diversity in themes; however, they did not come out as too overarching and ambitious, which might be a symptom of the lack of direction due to the ambiguous understanding of social sustainability overall.

The number of responses in relation to strategic guidelines was relatively few in comparison to the other levels. Potential reasons can be this is a relatively difficult concept to grasp, specifically when such thinking is not in play. Admittedly, a lack of answers could also have been due to a lack of clarity in the survey questions in relation to this FSSD level. Information to what guides strategic work and decisions was often found within answers to other questions/levels, such as 'Given the approach described above, would you add any other aspects to what the term social sustainability means or implies for your municipality?'. Nevertheless, aspects in relation to strategic guidelines were completed and further elaborated on during interviews with the best practice municipalities.

Actions seemed to support the roles of the people working with social sustainability, and the tools aligned well with the actions. Some of the municipalities mentioned very few actions; however, they were then formulated at a very or relatively high level. Such as 'internal consulting and support' or 'Preventive work on ANDGT'. A few municipalities, for example, Norrtälje, did not mention any actions at all in the survey, but instead wrote that the list of actions would be too extensive due to the broadness of sustainability work a municipality engages in.

\subsection{Reflections on Method}

The questions in part two of the survey, which was based on the sustainability principles, led to more (exhaustive answers) and seemed to have made the respondents also think about the nuances of the social sustainability work more. For example, the HR department and competence issues were not commonly mentioned in the answers in the first part of the survey. Some respondents, though, mentioned that it was difficult to understand what was meant by the principles and what answers were of interest. In line with these comments, not many municipalities seem to make real use of the structure of the FSSD, which supports simplicity without reduction and is the framework that they have partly signed on to. They also do not seem to make use of any other unifying and overarching structure, which might help them address the complexity and spend their limited resources more effectively. The reason why a more holistic definition of social sustainability along the lines of the FSSD might be advantageous is that, without a robust definition of social sustainability or a complete picture of the goal, one can easily fall into the trap of addressing one issue while, in turn, creating new or adding to existing social issues, e.g., one mechanism to create more influence might actually lead to more inequality in the long run as some groups might be able to make better use of the mechanism than others. An example might be digital tools for influence potentially excluding any group that does not want to or cannot easily engage with those tools, such as many elderly people. Another example might be excessive reliance on social media for engagement when there is evidence the use of social media can 
have detrimental health effects, especially for adolescence. Having a general but concrete definition and goal would help to highlight and better address potential trade-offs.

\subsection{Overall Reflections}

Interestingly, the municipalities that came out as most advanced were neither the biggest nor the smallest. Potentially the larger ones are simply too complex and too large to collaborate effectively, while the smaller ones potentially have too little human or other resources to do this work more systematically, even though they have a lower complexity of organization. While the study did reveal that the smaller municipalities were struggling the most with doing this work strategically, the issue of size and its relevance would need to be further investigated. In addition, the number of quotes or answers in relation to the FSSD levels, in general, did not seem to correlate at all with how advanced municipalities were in their work, which would emphasize the usefulness of a qualitative, more in-depth study to address the aim of this research.

Our findings connect to other work on barriers to strategic sustainability work in municipalities in general [46] and social sustainability specifically $[14,15,30]$. For example, many studies critique sustainability for being poorly defined $[6,8,44]$. Other commonly mentioned barriers are a lack of time and resources. One main, common, and overarching barrier is fragmented organizational structures [6,7,46-50]. Although most previous work did not focus specifically on social sustainability, it is not surprising that the organization of social sustainability work suffers from the same barriers, specifically the siloed organization of public administration. This becomes even more evident in this field as social sustainability touches almost all areas of work in a municipality and, therefore, increases the complexity. However, successful collaboration is essential in order to deal with governance barriers and to effectively address the dynamic sustainability challenge. This, in turn, demands us to take a systems perspective and to apply a strategic and unifying approach for full sustainability [19].

In line with the above, our main finding was that municipalities that are more advanced in their social sustainability work have managed to organize themselves in a way that at least partly overcomes the challenges of the silo approach engrained in municipal structures. They use common visions as well as extensive structures for collaboration, as Holmström and Karlsson [29] and Nilsson [31] also emphasized, to come together to address these department-spanning themes, even if they do not call them social sustainability but more traditional names such as Safety and Public Health work. In addition, and in line with Krause et al.'s [4] study on the organization of overall sustainability responsibility, more advanced municipalities often have a centrally placed unit in the organization that drives the social sustainability agenda, not the least, which was also underlined by Krause et al. [4] and Nilsson [31], as well as all the interviewees of best practices as an important force, they seem to benefit from strong leadership commitment.

The study brings with it some limitations, for example, the selection of the ecomunicipalities' network as the focus of the study as there could be other municipalities doing good (social) sustainability work that are not included in the network. However, the network provides easy access to municipalities that have committed to actively work together on these issues. While the study may not represent all Swedish municipalities, the procedure can be replicated to extend this study, and the best practices can be useful benchmarks for others. A further potential limitation is the selection of respondents. Each municipality has a main contact person for the network, to whom the survey was sent. In some cases, they were the best person to answer, such as a general sustainability strategist; however, in others, they were, e.g., an environmental strategist, which means they may not have been the most knowledgeable about the issue. Still, reviewing the positions of those answering the survey, it does look like the SEKOM contacts forwarded the survey to people in social sustainability positions to a great extent. Lastly, the social sustainability principles can, as already indicated, be challenging to access on a first encounter, and the fact that the second-round questions of the survey were based on this might have meant 
that not all were able to deepen their answers equally. However, since this was meant as a way to expand on part one, it seems safe to assume that "advanced" municipalities would have given a glimpse of such work already in part one also.

Regardless of these limitations, however, the study does highlight that municipalities are struggling with organizing their social sustainability work in a way that allows them to be strategic about it. Some municipalities manage to do so better with the help of robust structures and visions of socially sustainable municipalities and with real strategic plans. These lessons can be transferred to other municipalities to aid them in their work and help them move towards real social sustainability.

\section{Conclusions}

Through our study, we gained an up-to-date understanding of current social sustainability work in 21 Swedish eco-municipalities and identified three best practice examples that stood out from the others. Key features of these best practices regarding organization of social sustainability work were additional structures for collaboration across departments, with external actors, and across sectors. Striking for these municipalities was also how political and administrative leaders are active and had given clear(er) mandates to administration and that a common vision for social sustainability was communicated. While the organization of social sustainability work varies greatly between municipalities, best practices are better aligned with elements of strategic sustainable development work than less advanced municipalities on social sustainability. For municipal practitioners to be open for and appreciate support to strategically address social sustainability, it is important that said support also acknowledges municipalities' current reality. The results of this study provide an opportunity for municipal practitioners to gain an overview and to better situate their current reality from a strategic social sustainability perspective, which, in turn, can spark opportunities for improvement. This provides a foundation on which one can actively seek and develop support adapted to their specific context. Forthcoming work will build on this study to develop such support. Examples might be to support the development of cross-departmental and -organizational collaboration mechanisms, common goals, and connected accountability standards. A critical action research approach where support is developed through engaging with municipal practitioners, such as suggested by Wittmayer et al. [51], seems appropriate and also in line with ongoing research on methodological support for cross-sectoral municipal and regional strategic work for sustainability [52].

Author Contributions: Conceptualization, L.W. and M.M.; methodology, L.W and M.M.; data collection: L.W.; analysis L.W. and M.M. to a small degree.; writing-original draft preparation, L.W.; writing-review and editing, M.M. and L.W. All authors have read and agreed to the published version of the manuscript.

Funding: This research was funded by The National Association of Swedish Eco-municipalities and the municipalities of Hudiksvall, Karlskrona, and Lerum. In addition, funding was received from the FUTURA foundation. The APC was funded by the Blekinge Institute of Technology.

Institutional Review Board Statement: Not applicable.

Informed Consent Statement: Informed consent was obtained from all subjects involved in the study. Data Availability Statement: Not applicable.

Acknowledgments: We would like to express our gratitude to the Swedish Eco-municipalities' network for facilitating access to data and to the participants in both the survey and the interviews for their time, input, and commitment.

Conflicts of Interest: The authors declare no conflict of interest. The funders had no role in the design of the study; in the collection, analyses, or interpretation of data; in the writing of the manuscript; or in the decision to publish the results. 


\section{References}

1. Schuthof, R.; Kuhn, S.; Morrow, R.; Kotler, A. 15 Pathways to Localise the Sustainable Development Goals-Inspiration from Cities Implementing Local Actions Contributing to Global Goals; ICLEI Europe: Freiburg, Germany, 2019.

2. Keskitalo, E.C.H.; Liljenfeldt, J. Working with Sustainability: Experiences of Sustainability Processes in Swedish Municipalities. Nat. Resour. Forum 2012, 36, 16-27. [CrossRef]

3. Polk, M. Sustainability in Practice: The Interpretation of Sustainable Development in a Regional Planning Arena for Dialogue and Learning in Western Sweden. Plan. Theory Pract. 2010, 11, 481-497. [CrossRef]

4. Krause, R.M.; Feiock, R.C.; Hawkins, C.V. The Administrative Organization of Sustainability Within Local Government. J. Public Adm. Res. Theory 2016, 26, 113-127. [CrossRef]

5. Quitzau, M.-B.; Gustafsson, S.; Hoffmann, B.; Krantz, V. Sustainability Coordination within Forerunning Nordic MunicipalitiesExploring Structural Challenges across Departmental Silos and Hierarchies. J. Clean. Prod. 2022, 335, 130330. [CrossRef]

6. Burch, S. In Pursuit of Resilient, Low Carbon Communities: An Examination of Barriers to Action in Three Canadian Cities. Energy Policy 2010, 38, 7575-7585. [CrossRef]

7. Van Bueren, E.; De Jong, J. Establishing Sustainability: Policy Successes and Failures. Build. Res. Inf. 2007, 35, 543-556. [CrossRef]

8. McLean, B.L.; Borén, T. Barriers to Implementing Sustainability Locally: A Case Study of Policy Immobilities. Local Environ. 2015, 20, 1489-1506. [CrossRef]

9. Borén, S.; Nurhadi, L.; Ny, H.; Robèrt, K.-H.; Broman, G.; Trygg, L. A Strategic Approach to Sustainable Transport System Development - Part 2: The Case of a Vision for Electric Vehicle Systems in Southeast Sweden. J. Clean. Prod. 2017,140 Pt 1, 62-71. [CrossRef]

10. Marleau Donais, F.; Abi-Zeid, I.; Waygood, E.O.D.; Lavoie, R. Municipal Decision-Making for Sustainable Transportation: Towards Improving Current Practices for Street Rejuvenation in Canada. Transp. Res. Part A Policy Pract. 2022, 156, 152-170. [CrossRef]

11. Banister, D. Barriers to the Implementation of Urban Sustainability. Int. J. Environ. Pollut. 1998, 10, 65-83. [CrossRef]

12. Campbell, S. Green Cities, Growing Cities, Just Cities: Urban Planning and the Contradictions of Sustainable Development. J. Am. Plan. Assoc. 1996, 62, 296-312. [CrossRef]

13. Snowden, D.J.; Boone, M.E. A Leader's Framework for Decision Making (Cover Story). Harv. Bus. Rev. 2007, 85, 68-76. [PubMed]

14. Boström, M. A Missing Pillar? Challenges in Theorizing and Practicing Social Sustainability: Introduction to the Special Issue. Sustain. Sci. Pract. Policy 2012, 8, 3-14. [CrossRef]

15. Missimer, M. Social Sustainability within the Framework for Strategic Sustainable Development. Ph.D. Thesis, Blekinge Tekniska Högskola, Karlskrona, Sweden, 2015.

16. WCED. Our Common Future; Oxford University Press: Oxford, UK; New York, NY, USA, 1987; ISBN 978-0-19-282080-8.

17. United Nations Development Programme. Transforming Our World: The 2030 Agenda for Sustainable Development; Springer Publishing Company: New York, NY, USA, 2017.

18. SKR. Folkhälsomyndigheten Mötesplats Social Hållbarhet. Available online: https://www.folkhalsomyndigheten.se/motesplatssocial-hallbarhet/in-english/ (accessed on 1 December 2021).

19. Broman, G.I.; Robèrt, K.-H. A Framework for Strategic Sustainable Development. J. Clean. Prod. 2017, 140 Pt 1, 17-31. [CrossRef]

20. Woodcraft, S. Social Sustainability and New Communities: Moving from Concept to Practice in the UK. Procedia Soc. Behav. Sci. 2012, 68, 29-42. [CrossRef]

21. Liao, L.; Warner, M.E.; Homsy, G.C. Sustainability's Forgotten Third E: What Influences Local Government Actions on Social Equity? Local Environ. 2019, 24, 1197-1208. [CrossRef]

22. Moldavanova, A.; Goerdel, H.T. Understanding the Puzzle of Organizational Sustainability: Toward a Conceptual Framework of Organizational Social Connectedness and Sustainability. Public Manag. Rev. 2018, 20, 55-81. [CrossRef]

23. Paz, T.D.S.R.; Caiado, R.G.G.; Quelhas, O.L.G.; Gavião, L.O.; Lima, G.B.A. Assessment of Sustainable Development through a Multi-Criteria Approach: Application in Brazilian Municipalities. J. Environ. Manag. 2021, 282. [CrossRef]

24. Medved, P. Exploring the 'Just City Principles' within Two European Sustainable Neighbourhoods. J. Urban Des. 2018, 23, 414-431. [CrossRef]

25. Woodcraft, S. Understanding and Measuring Social Sustainability. J. Urban Regen. Renew. 2015, 8, 133-144.

26. Shirazi, M.R.; Keivani, R. The Triad of Social Sustainability: Defining and Measuring Social Sustainability of Urban Neighbourhoods. Urban Res. Pract. 2019, 12, 448-471. [CrossRef]

27. Ghahramanpouri, A.; Lamit, H.; Sedaghatnia, S. Urban Social Sustainability Trends in Research Literature. ASS 2013, 9, p185. [CrossRef]

28. Gustavsson, E.; Elander, I. Social Hållbarhet inte Bara "Sustainababble"? Från Mångtydig Vision Till Analytiskt Redskap vid Uppföljning av Stadsbyggnadsprojekt; Örebro Universitet: Örebro, Sweden, 2013.

29. Holmström, J.; Karlsson, E. Social Hållbarhet i Kommunal Planering: En Utredande Studie av Arbetet Med Social Hållbarhet i Tretton Kommuner. Bachelor's Thesis, Högskolan i Gävle, Gävle, Sweden, 2019.

30. SALAR. Swedish Association of Local Authorities and Regions. Available online: https://skr.se/skr/tjanster/englishpages.411. html (accessed on 20 November 2021).

31. Nilsson, V. Hållbar Kommun-Om Kommuners Arbete Med Social Hållbarhet; Det Nationella Kommunforskningsprogrammets Rapportserie; Kommunforskning i Västsverige: Göteborg, Sweden, 2016. 
32. Nationella Kommunforskningsprogrammet. Available online: https://www.natkom.se/index.htm (accessed on 20 January 2022$)$.

33. Missimer, M.; Robèrt, K.-H.; Broman, G. A Strategic Approach to Social Sustainability-Part 2: A Principle-Based Definition. J. Clean. Prod. 2017, 140 Pt 1, 42-52. [CrossRef]

34. Google Maps. Available online: https://www.google.se/maps/@60.1304657,9.407266,4.52z/data=!4m3!11m2!2sLbYsgeht1 wZXEh31Y_XebKWMregJSA!3e3 (accessed on 10 December 2021).

35. Robèrt, K.-H. Det Nödvändiga Steget; Affärsförl Mediautveckling: Stockholm, Sweden, 1992; ISBN 9789176301128.

36. Robèrt, K.-H.; Schmidt-Bleek, B.; Aloisi de Larderel, J.; Basile, G.; Jansen, J.L.; Kuehr, R.; Price Thomas, P.; Suzuki, M.; Hawken, P.; Wackernagel, M. Strategic Sustainable Development-Selection, Design and Synergies of Applied Tools. J. Clean. Prod. 2002, 10, 197-214. [CrossRef]

37. Mesquita, P.L.; Missimer, M. Social Sustainability Work in Product Development Organizations: An Empirical Study of Three Sweden-Based Companies. Sustainability 2021, 13, 1986. [CrossRef]

38. Dreborg, K.H. Essence of Backcasting. Futures 1996, 28, 813-828. [CrossRef]

39. SEKOM. Sveriges Ekokommuner-Världens Äldsta Kommunnätverk För Hållbar Utveckling. Available online: http://www. sekom.se/ (accessed on 1 January 2018).

40. Frey, B.B. The SAGE Encyclopedia of Educational Research, Measurement, and Evaluation; SAGE Publications, Inc.: Thousand Oaks, CA, USA, 2018; ISBN 978-1-5063-2615-3.

41. Corbin, J.; Strauss, A. Basics of Qualitative Research: Techniques and Procedures for Developing Grounded Theory, 3rd ed.; SAGE Publications, Inc.: Thousand Oaks, CA, USA, 2008; ISBN 978-1-4129-0644-9.

42. Finsam. Available online: https://www.finsam.se/ (accessed on 29 November 2021).

43. SKR. Jämställdhetsintegrering Genom Ömsesidigt Lärande. Available online: https://skr.se/skr/demokratiledningstyrning/ manskligarattigheterjamlikhet/jamstalldhet/jamstalldhetsintegrering/modellkommunerochregioner.10200.html (accessed on 29 November 2021).

44. Försäkringskassan (The Swedish Social Insurance Agency). Available online: http://www.forsakringskassan.se/english (accessed on 20 November 2021).

45. Arbetsförmedlingen (Swedish Public Emplyment Service). Available online: https:/ /arbetsformedlingen.se/other-languages/ english-engelska / do-you-want-to-work-in-sweden (accessed on 20 November 2021).

46. Ling, C.; Hanna, K.; Dale, A. A Template for Integrated Community Sustainability Planning. Environ. Manag. 2009, 44, 228-242. [CrossRef]

47. Stuart, J.; Collins, P.; Alger, M.; Whitelaw, G. Embracing Sustainability: The Incorporation of Sustainability Principles in Municipal Planning and Policy in Four Mid-Sized Municipalities in Ontario, Canada. Local Environ. 2014, 21, 219-240. [CrossRef]

48. Fazey, I.; Schäpke, N.; Caniglia, G.; Patterson, J.; Hultman, J.; van Mierlo, B.; Säwe, F.; Wiek, A.; Wittmayer, J.; Aldunce, P.; et al. Ten Essentials for Action-Oriented and Second Order Energy Transitions, Transformations and Climate Change Research. Energy Res. Soc. Sci. 2018, 40, 54-70. [CrossRef]

49. Höjer, M.; Wangel, J. Smart Sustainable Cities: Definition and Challenges. Adv. Intell. Syst. Comput. 2014, 310, 333-349. [CrossRef]

50. Howarth, C.; Monasterolo, I. Understanding Barriers to Decision Making in the UK Energy-Food-Water Nexus: The Added Value of Interdisciplinary Approaches. Environ. Sci. Policy 2016, 61, 53-60. [CrossRef]

51. Wittmayer, J.M.; van, S.; Rok, A.; Roorda, C. Governing Sustainability: A Dialogue between Local Agenda 21 and Transition Management. Local Environ. 2016, 21, 939-955. [CrossRef]

52. Wälitalo, L. Introductory Methodological Support for Cross-Sectoral Municipal and Regional Strategic Work for Sustainability. Licentiate Thesis, Blekinge Tekniska Högskola, Karlskrona, Sweden, 2020. 